\title{
Zinc regulates reactive oxygen species generation in platelets
}

Article

Accepted Version

lopes Pires, M. E., Ahmed, N. S., Vara, D., Gibbins, J. M. ORCID: https://orcid.org/0000-0002-0372-5352, Pula, G. and Pugh, N. (2020) Zinc regulates reactive oxygen species generation in platelets. Platelets, 32 (3). pp. 368-377. ISSN 0953-7104 doi:

https://doi.org/10.1080/09537104.2020.1742311 Available at https://centaur.reading.ac.uk/89790/

It is advisable to refer to the publisher's version if you intend to cite from the work. See Guidance on citing.

To link to this article DOI: http://dx.doi.org/10.1080/09537104.2020.1742311

Publisher: Taylor \& Francis

All outputs in CentAUR are protected by Intellectual Property Rights law, including copyright law. Copyright and IPR is retained by the creators or other copyright holders. Terms and conditions for use of this material are defined in the End User Agreement.

\section{www.reading.ac.uk/centaur}

\section{CentAUR}


Central Archive at the University of Reading

Reading's research outputs online 


\title{
Zinc regulates reactive oxygen species generation in platelets
}

\author{
Running Head: $\mathrm{Zn}^{2+}$ regulates platelet ROS production \\ M.E. Lopes Pires ${ }^{1}$, N. S. Ahmed¹, D. Vara², J. M. Gibbins³ ${ }^{3}$ G. Pula and N. Pugh¹.
}

Short running head: $\mathrm{Zn}^{2+}$ regulates platelet ROS production

Dr. Maria E. Lopes Pires, PhD: Department of Biomedical and Forensic Sciences, Anglia Ruskin University, Cambridge, UK, CB1 1PT

Dr. Niaz S. Ahmed, PhD: Department of Biomedical and Forensic Sciences, Anglia Ruskin University, Cambridge, UK, CB1 1PT

Dr Dina Vara, PhD: College of Medicine and Health, University of Exeter, Exeter, UK.

Dr Jonathan M. Gibbins, PhD: Institute for Cardiovascular \& Metabolic Research, University of Reading, Reading, UK.

Dr. Giordano Pula, PhD: University Medical Center Eppendorf Hamburg Institute for Clinical Chemistry and Laboratory Medicine, Hamburg, Germany

Dr. Nicholas Pugh, PhD (Corresponding author)

School of Life Sciences,

Anglia Ruskin University, 
East Road,

Cambridge, CB1 1PT.

E: Nicholas.Pugh@anglia.ac.uk

Orcid: 0000-0002-6916-4199

Tel: +448451962661

\section{What is known on this topic}

- Platelets produce ROS in response to activation during thrombosis

- Exogenous Zinc acts as platelet agonist

- Zinc is an intracellular secondary messenger in platelets

- ROS production is regulated by NADPH oxidases, and involves signalling via MAPK family members

\section{What this paper adds}

- Fluctuations of intracellular $\mathrm{Zn}^{2+}$ in platelets regulates ROS production

- $\mathrm{Zn}^{2+}$-dependent ROS production is dependent on NADPH oxidase and mitochondria activity, and is regulated by Erk1/2 and JNK

- This is the first work to demonstrate a role for zinc in platelet ROS generation.

\section{Abstract}

Vascular complications resulting from atherosclerosis development are a major cause of death. Reactive oxygen species (ROS) are produced by platelets during activation, and have been demonstrated to positively regulate platelet activatory responses. $\mathrm{Zn}^{2+}$ 
is also an important haemostatic cofactor in platelets, acting both as a platelet agonist and secondary messenger. Whilst the effect of $\mathrm{Zn}^{2+}$-dependent signalling mechanisms on ROS production in nucleated cells has been demonstrated, comparable roles in platelets have yet to be investigated. In this study we investigate the relationship between fluctuations in cytosolic $\mathrm{Zn}^{2}\left[\mathrm{Zn}^{2+}\right]_{i}$ and platelet ROS production. Agonistevoked ROS production, GSH levels and GPx activity are abrogated in platelets treated with the $\mathrm{Zn}^{2+}$-chelator, TPEN. Conversely, increasing platelet $\left[\mathrm{Zn}^{2+}\right]_{i}$ using $\mathrm{Zn}^{2+}$ ionophores potentiated ROS generation and decreased GSH levels and GPx activity. $\mathrm{Zn}^{2+}$-dependent ROS production was sensitive to pretreatment with DPI or mitoTEMPO, a NADPH oxidase and mitochondria inhibitors respectively. Increasing $\left[\mathrm{Zn}^{2+}\right] \mathrm{i}$ resulted in increases of Erk1/2 and JNK phosphorylation. Our data are consistent with a functional association between $\left[\mathrm{Zn}^{2+}\right]_{i}$ and ROS production in platelets that could influence thrombus formation in a clinical context.

\section{Keywords}

Zinc, platelets, ROS, signal transduction, thrombosis 


\section{Introduction}

Complications resulting from atherosclerosis development are a major cause of mortality and morbidity.[1] Atherosclerotic plaques develop as a result of chronic inflammation, with inflammatory signals activating endothelial cells, leading to leukocyte infiltration. Platelets also cooperate in inflammatory processes leading to plaque development and tissue reconstruction.[1,2] The evolution of atherosclerotic plaques and their subsequent rupture, are responsible for myocardial infarction and stroke.[3]

Zinc $\left(\mathrm{Zn}^{2+}\right)$ is an important regulator of intra- and extracellular physiological processes in a variety of cell types. Local, extracellular $\mathrm{Zn}^{2+}$ levels significantly increase in the initial inflammatory phase following injury, and have been shown to facilitate wound healing.[4,5] Furthermore, levels of $\mathrm{Zn}^{2+}$ in atherosclerotic plaques are approximately six times greater than in healthy tissues.[6] $\mathrm{As} \mathrm{Zn}^{2+}$ is present in the $\alpha$ granules of platelets, degranulation is likely to result in localised increases in $\mathrm{Zn}^{2+},[7]$ which could regulate haemostatic processes. $\mathrm{Zn}^{2+}$ has been shown to have important functions in haemostasis. Bleeding irregularities are correlated with low zinc diets in humans and rodents.[8,9] Exogenous $\mathrm{Zn}^{2+}$ acts as a platelet agonist, being able to cross platelet membranes to initiate platelet aggregatory mechanisms in a manner that is dependent on PKC. $[10,11]$ Recent work has demonstrated that intracellular $\mathrm{Zn}^{2+}$ $\left(\left[\mathrm{Zn}^{2+}\right]_{\mathrm{i}}\right)$ increases in the platelet cytosol as a result of agonist stimulation, an a manner consistent with a secondary messenger.[12] In this work it was shown that agonistevoked increases in $\left[\mathrm{Zn}^{2+}\right]_{i}$ were sensitive to the platelet redox state, suggestive of a role for thiol groups on $\mathrm{Zn}^{2+}$ binding proteins.

Whilst reactive oxygen species (ROS) are produced as a result of the habitual metabolism of cells, chronic and acute overproduction of ROS is associated with the 
development of cardiovascular disease, hypertension, diabetes, hypercholesterolemia, thrombotic diseases and metabolic syndrome.[13-16] The principal forms of ROS are superoxide anion $\left(\mathrm{O}_{2}{ }^{--}\right)$, hydrogen peroxide $\left(\mathrm{H}_{2} \mathrm{O}_{2}\right)$, hydroxyl radicals $\left(\mathrm{OH}^{\circ}\right)$, and hypochlorous acid $(\mathrm{HOCl})$. These are endogenously produced from distinct sources via the action of enzymes including NADPH oxidase, xanthine oxidase, lipoxygenase, cyclooxygenase, and components of the mitochondria electron transport chain. [17]. In low concentrations, ROS plays a role in the function of cell processes .[19] At higher concentrations, ROS production results in damage to cell components, including lipids, nucleic acids and proteins.[20] This damage impairs regular cell activity and can lead to the release of secondary reactive species which can do further damage, contributing to a development of different diseases.[16,21-23]

The mechanisms that lead to the release of ROS from nucleated cells have been investigated, and the involvement of $\mathrm{Zn}^{2+}$ in this process has been assessed. Treatment of cells with $\mathrm{Zn}^{2+}$ promotes increases in ROS generation as a result of NADPH oxidase activity.[24,25] $\mathrm{Zn}^{2+}$-treatment results in damage to renal cells in vitro, concomitantly with a raise of ROS release and promote the activation of p67phox, a NADPH oxidase subunit.[26] ROS production in numerous cell types correlates with $\mathrm{Zn}^{2+}$-dependent regulation of NOX expression $[27,28]$ and mitochondria activation[2931]. However, the effect of exogenous or endogenous $\mathrm{Zn}^{2+}$ on $\mathrm{ROS}$ production in platelets is yet to be investigated. Here, we show that increasing $\left[\mathrm{Zn}^{2+}\right] \mathrm{i}$, via either exogenously applied $\mathrm{Zn}^{2+}$ or agonist evoked increases in $\left[\mathrm{Zn}^{2+}\right]_{i}$ regulates $\mathrm{ROS}$ generation in a manner that is dependent on NADPH oxidase and mitochondria activation, and is regulated by MAPK phosphorylation. These data indicate that increases in platelet $\left[\mathrm{Zn}^{2+}\right]_{i}$ either from ruptured atherosclerotic plaques, or from 
agonist evoked release from intracellular stores, couple ROS production to platelet activation. 


\section{MATERIALS AND METHODS}

\section{Materials}

Cross-linked collagen-related peptide (CRP-XL; GpVI agonist) was from Professor Richard Farndale (Cambridge, UK), U46619 (TPa receptor agonist) was from Tocris (Bristol, UK), thrombin (PAR agonist) was from Sigma Aldrich (Poole, UK). The cell-permeable superoxide indicator dihydroethidium (DHE) was from Abcam (Cambridge, UK). The NADPH oxidase inhibitor diphenyleneiodonium chloride (DPI) was from Tocris. The mitochondrial targeted anti-oxidant, mitoTEMPO was from Sigma Aldrich (Poole, UK) Clioquinol, (Cq, $\mathrm{Zn}^{2+}$ ionophore, $\mathrm{C}_{9} \mathrm{H}_{5} \mathrm{CIINO}, \mathrm{K}_{d} \mathrm{Zn}: 10^{-7} \mathrm{M}$, $\left.\mathrm{KdCa}: \quad 0^{-4.9} \mathrm{M}\right), \quad \mathrm{A} 23187\left(\mathrm{Ca}^{2+}\right.$ ionophore, $\left.\mathrm{C}_{29} \mathrm{H}_{37} \mathrm{~N}_{3} \mathrm{O}_{6}\right), \quad \mathrm{N}, \mathrm{N}, \mathrm{N}^{\prime}, \mathrm{N}^{\prime}-$ Tetrakis(2pyridylmethyl) ethylenediamine (TPEN, $\mathrm{Zn}^{2+}$ chelator, $\mathrm{K}_{d} \mathrm{Zn}: 2.6 \times 10^{-16} \mathrm{M}, \mathrm{K}_{\mathrm{d}} \mathrm{Ca}: 4.4 \times 10^{-}$ $\left.{ }^{5} \mathrm{M}\right)$, DM-BAPTA-AM $\left(\mathrm{C}_{34} \mathrm{H}_{40} \mathrm{~N}_{2} \mathrm{O}_{18}, \mathrm{~K}_{d} \mathrm{Zn}: 7.9 \times 10^{-9} \mathrm{M}, \mathrm{K}_{d} \mathrm{Ca}: 110 \times 10^{-9} \mathrm{M}\right)$, and membrane permeant anti-oxidising proteins, PEG-Super oxidise dismutase (SOD) and PEG-Catalase (CAT) were from Sigma Aldrich.

The NADPH oxidase inhibitor DPI and the mitochondrial-targeted antioxidant inhibitor mitoTEMPO were from Sigma.

For immunoblotting, specific antibodies against various signalling proteins (phospho-Erk1/2 (Thr202/Tyr204), phospho-JNK (Thr183/Tyr185), p47phox, phospho-p47phox) were obtained from Santa Cruz Antibodies, USA or Thermofisher, UK (sc136521, sc293136, sc6254, sc17845 and PA5 36863 respectively). Rabbit $\beta$ actin antibody was from (Cell Signalling, UK; \#4970). Secondary antibodies Cy5 goat anti-rabbit $\lg G$ and Cy3 goat anti-mouse $\lg G$ antibodies were obtained from Cell Signalling. Cell-permeable superoxide-specific spin probe 3-methoxycarbonyl-2,2,5,5- 
tetramethylpyrrolidine $(\mathrm{CMH})$. Unless stated, all other reagents were from Sigma Aldrich.

\section{Platelet preparation}

This study was approved by the Faculty Research Ethics Committee at Anglia Ruskin University and informed consent was obtained in accordance with the Declaration of Helsinki. Blood was donated by healthy human volunteers, free from medication for two weeks. Blood was collected into $11 \mathrm{mM}$ sodium citrate and washed platelets were prepared as described previously.[11]

\section{DHE-based detection of platelet ROS by flow cytometry}

Platelet suspensions $\left(2 \times 10^{8}\right.$ cells $\left./ \mathrm{mL}\right)$ were rested for $30 \mathrm{mins}$ at $37^{\circ} \mathrm{C}$, prior to being loaded with $10 \mu \mathrm{M}$ of dihydroethidium (DHE) for 15 mins in the dark at $37^{\circ} \mathrm{C}$. Platelets were pre-incubated for 15 mins with diphenyleneiodonium (DPI, $10 \mu \mathrm{M})$, mitoTEMPO $(10 \mu \mathrm{M})$, TPEN $(50 \mu \mathrm{M})$, U0126 $(10 \mu \mathrm{M})$ and SP600 $(10 \mu \mathrm{M})$ prior to stimulation with $\mathrm{ZnSO}_{4}(10-300 \mu \mathrm{M})$, Clioquinol $(100 \mu \mathrm{M})$, or $\mathrm{A} 23187(100 \mu \mathrm{M})$. To investigate the influence of $\mathrm{Zn}^{2+}$ on agonist evoked ROS responses, platelets were pre-treated for 10 minutes with TPEN $(50 \mu \mathrm{M})$ prior to stimulation with thrombin $(1 \mathrm{U} / \mathrm{mL})$ or $\mathrm{CRP}-\mathrm{XL}$ $(1 \mu \mathrm{g} / \mathrm{mL})$. Following treatment, platelets suspensions were diluted $1: 10$ in cold modified $\mathrm{Ca}^{2+}$-free Tyrodes buffer (CFT, in mM: $140 \mathrm{NaCl}, 5 \mathrm{KCl}, 10 \mathrm{HEPES}, 5$ Glucose, $\left.0.42 \mathrm{NaH}_{2} \mathrm{PO}_{4}, 12 \mathrm{NaHCO}_{3}, \mathrm{pH} 7.4\right)$ and were analysed by flow cytometry using an Accuri C6 flow cytometer (BD, UK). Data were acquired from 10,000 cells and recorded as percentage of cells positive or median fluorescence intensity (MFI).

\section{Oxygen radical detection using Electron Spin Resonance (ESR)}


As previously described [19], washed platelet suspensions $\left(2 \times 10^{8} / \mathrm{mL}\right)$ were loaded with $\mathrm{CMH}(200 \mu \mathrm{M}$, in the presence of $25 \mu \mathrm{M}$ deferoxamine and $5 \mu \mathrm{M}$ DETC) for 10 minutes at room temperature. Platelet suspensions were loaded onto a Chronolog $700-2$ aggregometer with continuous stirring $\left(1,200 \mathrm{rpm}\right.$ at $\left.37^{\circ} \mathrm{C}\right)$ and the turbidimetry readings were recorded. After 1 minute, $\mathrm{ZnSO}_{4}(10-300 \mu \mathrm{M})$, clioquinol $(100 \mu \mathrm{M})$ or A23187 $(100 \mu \mathrm{M})$ were added and aggregation was measured for 10 minutes. Following aggregation, platelet solution was centrifuged by $14,000 \mathrm{~g}$ and $50 \mu \mathrm{l}$ of platelet-free supernatant was transferred into the Hirschmann precision micropipettes and read using an e-scan (Noxygen, Germany). ESR spectra were recorded using the following ESR settings: centre field 3,492.5G, field sweep 60G, modulation amplitude 2G, sweep time 10s, number of scans 10 , microwave frequency 9.39GHz, microwave power $20 \mathrm{~mW}$, conversion time, $327.68 \mathrm{~ms}$, time constant, 5242.88ms..

\section{Reduced Glutathione (GSG) content and Glutathione Peroxidase (GPx) activity} Washed platelet suspensions $\left(2 \times 10^{8} / \mathrm{mL}\right)$ were stimulated with Clioquinol $(100 \mu \mathrm{M})$ or A23187 $(100 \mu \mathrm{M})$, or pre- incubated with TPEN $(50 \mu \mathrm{M})$ for 10 min prior to stimulation with thrombin $(1 \mathrm{U} / \mathrm{mL})$ or CRP-XL $(1 \mu \mathrm{g} / \mathrm{mL})$. Platelet $\mathrm{GSH}$ and GPx activity were determined by Amplte ${ }^{\top M}$ Fluorimetric Glutathione Assay Kit from AAT Bioquest $₫$ and EnzyChrom $^{\mathrm{TM}}$ Glutathione Peroxidase Assay Kit from BioAssay Systems, respectively, as described previously.[16,32]

\section{Confocal microscopy}

Washed platelet suspensions $\left(2 \times 10^{8} / \mathrm{mL}\right)$ were loaded with $10 \mu \mathrm{M} \mathrm{DHE}$ in the dark for 15 minutes at $37^{\circ}$. Suspensions were incubated with Clioquinol $(100 \mu \mathrm{M}), \mathrm{A} 23187$ 
$(100 \mu \mathrm{M})$, and adhere to fibrinogen-coated coverslips $(100 \mu \mathrm{M})$, during which images were acquired using a LSM510/Axiovert laser scanning confocal microscope with 60x oil NA1.45 objective (Zeiss, UK). Excitation and emission wavelengths were 420 and $590 \mathrm{~nm}$ respectively

\section{Immunoblot assay}

SDS-PAGE and immunoblotting were performed using standard protocols as described previously.[33] Rabbit $\beta$-actin antibody (Cell Signalling, UK; catalogue number: \#4970) was used to ensure equivalent levels of protein. Blots were visualised using enhanced chemiluminescence solution (ECL) (GE healthcare, UK). ImageJ (v1.45, NIH, Bethesda, USA) was used for quantification of protein bands.

\section{Data Analysis}

Data were analysed in GraphPad Prism by two-way ANOVA followed by Tukey's post hoc test. Data are means \pm SEM of at least four independent experiments. Significance is denoted as ${ }^{* *}(P<0.001),{ }^{* *}(P<0.01)$ or * $(P<0.05)$ 


\section{Results}

\section{External $\mathrm{Zn}^{2+}$ induces ROS generation by unstimulated platelets}

The recruitment of platelets to areas of endothelial damage, followed by platelet activation, culminates in thrombus formation.[2,34] Activated platelets release ROS, potentially affecting platelets and other cells in a paracrine manner.[35] Whilst exogenous $\mathrm{Zn}^{2+}$ has been found to act as a platelet agonist $[11,12,36]$, the effect of $\mathrm{Zn}^{2+}$ on platelet ROS production have yet to be investigated. Changes in ROS production in response to increasing concentrations of $\mathrm{ZnSO}_{4}(10-300 \mu \mathrm{M})$, was investigated in washed platelet suspensions loaded with DHE,. Using fluorometry, DHE fluorescence increased following treatment with low concentrations of $\mathrm{Zn}^{2+}$. DHE fluorescence $(A U)$ increased from a basal level of $551 \pm 52$, to $1767 \pm 146,1100 \pm 108$, $785 \pm 53$ and $996 \pm 131$ following treatment with $10,30,100$ and $300 \mu \mathrm{M}$ of $\mathrm{ZnSO}_{4}$ respectively $(p<0.05$, Figure $1 a)$.

ESR was employed to analyse superoxide anion production, as this is the most direct and reliable technique to identify chemical species that present one or more unpaired electrons.[14] Platelets were loaded with the cell-permeable superoxidespecific spin probe $\mathrm{CMH}(200 \mu \mathrm{M})$ prior to ESR analysis. Treatment with $\mathrm{Zn}^{2+}(10-$ $300 \mu \mathrm{M}$ ) resulted in changes to ESR intensity from basal levels (a representative ESR trace is shown in Figure $1 \mathrm{~b}$ ), confirming that $\mathrm{Zn}^{2+}$ treatment increases ROS production in platelets.

\section{$\left[\mathrm{Zn}^{2+}\right]_{i}$ is required for agonist dependent $\mathrm{ROS}$ release}

$\mathrm{Zn}^{2+}$ is present in platelet $\alpha$ granules and also in the platelet cytosol where it is likely to associate with cation-binding proteins [12]. Platelet activation results in 
increases in cytosolic $\mathrm{Zn}^{2+}$ concentration, consistent with release from intracellular stores.[12] To assess the influence of intracellular $\mathrm{Zn}^{2+}$ on ROS generation, platelet suspensions were preincubated with the intracellular $\mathrm{Zn}^{2+}$ chelator TPEN $(50 \mu \mathrm{M})$ prior to stimulation with thrombin $(1 \mathrm{U} / \mathrm{mL})$ or CRP-XL $(1 \mu \mathrm{g} / \mathrm{mL})$. In TPEN pretreated platelets, agonist-stimulated DHE fluorescence was reduced to basal levels. TPEN pretreatment reduced thrombin- or CRP-XL-mediated DHE fluorescence from $7432 \pm 637$ and $5951 \pm 255$, to $4320 \pm 147$ and $3690 \pm 195$ respectively $(p<0.05$, Figure 2a).

The glutathione redox complex acts as a buffer, protecting cells from overproduction of ROS.[37] ROS production in platelets results in changes in the relative concentrations of reduced (GSH) and oxidised glutathione (GSSG), and also in degradation of GPx is to hydrogen peroxide $\left(\mathrm{H}_{2} \mathrm{O}_{2}\right)$.[38] Levels of GSH and GPX activity in response to agonist stimulation in TPEN-pretreated platelets was quantified to investigate a role for $\mathrm{Zn}^{2+}$ in agonist-evoked ROS production. Stimulation of platelets with thrombin $(1 \mathrm{U} / \mathrm{mL})$ or CRP-XL $(1 \mu \mathrm{g} / \mathrm{mL})$ reduced $\mathrm{GSH}$ and $\mathrm{GSH}$ peroxidase (GPx) levels by approximately $50 \%$ and $30 \%$ respectively (Figures $2 b, c$ ). Thrombin and CRP-XL treatment reduced $\mathrm{GSH}$ to $0.39 \pm 0.03 \mu \mathrm{M}$ and $0.46 \pm 0.01 \mu \mathrm{M}$ respectively, relative to vehicle treatment $(0.58 \pm 0.09 \mu \mathrm{M})$. Similarly, GPx activity was reduced from $6.6 \pm 0.2 \mathrm{U} / \mathrm{mL}$ to $4.7 \pm 0.12 \mathrm{U} / \mathrm{mL}$ and $4.1 \pm 0.18 \mathrm{U} / \mathrm{mL}$ in response to thrombin and CRP-XL respectively.

Agonist evoked reductions of GSH levels and GPx activity were abrogated in TPEN pre-treatment platelets. TPEN induced an increase of $50 \%$ and $42.5 \%$ on GSH levels of platelets stimulated with thrombin and CRP-XL respectively, comparing with platelets in absence of TPEN (GSH level in TPEN-pretreated platelets was 
$0.78 \pm 0.06 \mu \mathrm{M}$ and $0.80 \pm 0.09 \mu \mathrm{M}$ following thrombin $(1 \mathrm{U} / \mathrm{mL})$ or CRP-XL- $(1 \mu \mathrm{g} / \mathrm{mL})$ mediated stimulation respectively).

Similarly, GPx activity following stimulation was increased in TPEN-pretreated platelets relative to untreated platelets. GPx activity in TPEN pretreated platelets increased by approximately $30 \%$ and $24 \%$ following with thrombin and CRP-XL respectively (GPx activity in TPEN-pretreated platelets was $6.8 \pm 0.2$ and $5.4 \pm 0.03$ following stimulation with thrombin and CRP-XL respectively, Figures $2 b, c)$. These data are consistent with a role for $\left[\mathrm{Zn}^{2+}\right]_{i}$ in regulation of agonist-dependent ROS production. Whether this effect is attributable to agonist-evoked increases in $\left[\mathrm{Zn}^{2+}\right]_{\mathrm{i}},[12]$ or to the perturbation of obligate $\mathrm{Zn}^{2+}$-binding proteins is unclear.

\section{ROS generation is correlated with increases in $\left[\mathrm{Zn}^{2+}\right] \mathrm{i}$}

Ionophores have previously been used to increase the concentration of cytosolic cations, mimicking cation release from intracellular stores.[39-41] Whilst A23187 has been widely used to investigate the effects of increases of cytosolic $\mathrm{Ca}^{2+}$ on cell or platelet function, it should be noted that this is a non-specific cation ionophore. Conversely, the $\mathrm{Zn}^{2+}$-specific ionophores clioquinol and pyrithione have previously been used to model increases in $\left[\mathrm{Zn}^{2+}\right]_{i}$ in platelets and other cells. $[12,42,43]$ To analyse the effects of increases of $\mathrm{Zn}^{2+}$ on platelet ROS production.

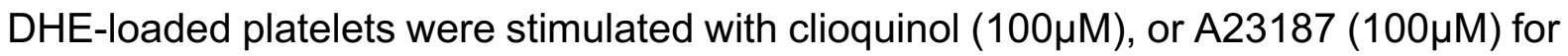
10 minutes, and changes in fluorescence were quantified using flow cytometry. As previously described, [44] A23187 treatment increased DHE fluorescence to $1735 \pm 176 \mathrm{AU}$ compared to the 745. $\pm 27 \mathrm{AU}$ for the vehicle control (DMSO, $p<0.05$, Figure 3a). Similarly clioquinol treatment resulted in increases of DHE fluorescence to 1824 $\pm 227 \mathrm{AU}(p<0.05$, Fig. 3A). ESR revealed ionophore-dependent increases in ROS 
production, with both A23187 and clioquinol increasing the oxidation rate of the spin probe $\mathrm{CMH}$ (Figure 3b). Changes in ionophore-mediated increases in ROS production were also assessed using confocal imaging of DHE-stained platelets. Treatment with A23187 or clioquinol both increased the number of DHE-positive platelets. Whilst both ionophores resulted in increases in ROS, the number of platelet staining positive following A23187 treatment was higher than that for clioquinol-treated platelets. Thus, increases in both $\left[\mathrm{Zn}^{2+}\right]_{i}$ and $\left[\mathrm{Ca}^{2+}\right]_{i}$ are able to mediated increases in ROS production (Figure 3c).

To further assess the influence of increases in $\left[\mathrm{Zn}^{2+}\right]_{i}$ on ROS production, changes in GSH level and GPx activity in response to ionophore treatment were investigated. GSH levels and GPx activity decreased upon ionophore treatment (Figures 3d, e). Levels of GSH were reduced from $0.5 \pm 0.03 \mu \mathrm{g} / \mathrm{mL}$ to $0.29 \pm 0.02 \mu \mathrm{g} / \mathrm{mL}$ and $0.31 \pm 0.01$ in response to $\mathrm{A} 23187$ or clioquinol respectively. Similarly, GPx activity was reduced from $6.8 \pm 0.15 \mathrm{U} / \mathrm{mL}$ to $4.9 \pm 0.2 \mathrm{U} / \mathrm{mL}$ and to $4.4 \pm 0.3 \mathrm{U} / \mathrm{mL}$ following A23187 or clioquinol treatment respectively. These data indicate that increases of $\left[\mathrm{Ca}^{2+}\right]_{i}$ or $\left[\mathrm{Zn}^{2+}\right]_{i}$ result in a pro-oxidative state, potentially caused by increased ROS levels and subsequent modification of the glutathione redox system.

\section{$\left[\mathrm{Zn}^{2+}\right]$--mediated ROS production is mediated by NADPH oxidase and} mitochondrial activity.

Both $\mathrm{Ca}^{2+}$ and $\mathrm{Zn}^{2+}$ have been shown to regulate $\mathrm{ROS}$ production via potentiation of independent mitochondria activity and NOX expression in nucleated cells.[27-31] To determine whether $\mathrm{Zn}^{2+}$-mediated ROS increases in platelets are due to NADPH oxidase or by activity of mitochondrial platelet, DHE-loaded platelets were treated with DPI $(10 \mu \mathrm{M})$ or mitochondrial mitoTEMPO $(10 \mu \mathrm{M})$ (a NADPH oxidase 
inhibitor and mitochondria-targeted antioxidant, respectively) prior to stimulation with clioquinol $(100 \mu \mathrm{M})$ or $\mathrm{A} 23187(100 \mu \mathrm{M})$, and ROS responses were quantified using flow cytometry. DHE fluorescence in DPI- and mitoTEMPO-pretreated platelets was reduced following stimulation with A23187 or clioquinol (Fig. 4A). A23187mediated ROS generation was reduced from $2170 \pm 149 A U$ to $1013 \pm 161$ and $965 \pm 170 \mathrm{AU}$ in DPI and mitoTEMPO treated platelets respectively. Similarly, clioquinol-mediated ROS generation was reduced from $3240 \pm 381$ to $9610 \pm 172$ and $919 \pm 140$ in DPI and mitoTEMPO treated platelets respectively.

NADPH oxidase activation is associated with phosphorylation events leading to association of various subunits under the control of p47phox.[45,46] Immunoblotting was performed to investigate whether ionophore-mediated increases of $\left[\mathrm{Zn}^{2+}\right]$ i resulted in changes in the p47phox phosphorylation state. Treatment of washed platelet suspensions with A23187 or clioquinol resulted in increases in p47phox phosphorylation (from $0.75 \pm 0.03 \mathrm{AU}$ to $1.08 \pm 0.07 \mathrm{AU}$ and $1.14 \pm 0.1$ following $\mathrm{A} 23187$ and clioquinol treatment respectively, $p<0.05$, Figures $4 b, c)$. This observation supports a role for NADPH oxidase in cation-dependent ROS production.

\section{$\mathrm{Zn}^{2+}$-mediated ROS generation induces Erk1/2 and JNK phosphorylation}

$\mathrm{Zn}^{2+}$-dependent activation of nucleated cells by $\mathrm{Zn}^{2+}$ is associated with concurrent MAPK activation.[47,48] To assess the effect of $\left[\mathrm{Zn}^{2+}\right]$ i on MAPKdependent signalling in platelets, we employed immunoblotting to quantify Erk1/2 (Thr202/Tyr204) and JNK (Thr183/Tyr185) phosphorylation, in response to ionophore treatment. Incubation of platelets with clioquinol $(100 \mu \mathrm{M})$ resulted in increases of phosphorylation of both Erk1/2 and JNK (Fig 5). Quantification of immunoblots showed that clioquinol treatment resulted in increases in phosphorylation of Erk1/2 from 
$1.0 \pm 0.07$ to $2.5 \pm 0.34 \mathrm{AU}$, whilst JNK phosphorylation increased from $1.97 \pm 0.29 \mathrm{AU}$ to 3.8 $\pm 0.17 \mathrm{AU}$ relative to vehicle control (Figure 5a, $\mathrm{p}<0.05)$. A23187 treatment $(100 \mu \mathrm{M})$ did not significantly change the levels of phosphorylation of either Erk1/2 or JNK (Figure 5a). Further experiments were performed to investigate the role of $\mathrm{Zn}^{2+}$ in agonist-evoked phosphorylation events. Stimulation of platelets with thrombin $(1 \mathrm{U} / \mathrm{mL})$ resulted increases in phosphorylation of Erk1/2 and JNK respectively. Phosphorylation of Erk1/2 increased from $2.0 \pm 0.2 \mathrm{AU}$ to $4.26 \pm 0.24 \mathrm{AU}$, whilst JNK increased from 1.6 $\pm 0.52 \mathrm{AU}$ to $5.33 \pm 0.33 \mathrm{AU}$, (Figure $5 \mathrm{~b}, \mathrm{p}<0.05$ ). Agonist-evoked phosphorylation was abrogated in TPEN treated platelets (Erk1/2 phosphorylation was reduced to 4.26 \pm 0.24 , and JNK to $2.89 \pm 0.49$ in TPEN pre-treatment platelets). Stimulation with CRP-XL $(1 \mu \mathrm{g} / \mathrm{mL})$ did not result in phosphorylation of either kinase. These data indicate a specific signalling response leading to Erk1/2 and JNK phosphorylation that is dependent on $\mathrm{Zn}^{2+}$, and independent of $\mathrm{Ca}^{2+}$

Previous work has demonstrated an association between MAPK activity and $\mathrm{Zn}^{2+}$-mediated changes in the redox state in nucleated cells.[26,49] To investigate the role of the platelet redox state in $\mathrm{Zn}^{2+}$-mediated ROS production, DHE-loaded platelets were pre-treated with DPI $(10 \mu \mathrm{M})$ or mitoTEMPO $(10 \mu \mathrm{M})$ prior to stimulation with clioquinol $(100 \mu \mathrm{M})$. DPI or mitoTEMPO pre-treatment reduced Erk1/2 and JNK phosphorylation from $7.3 \pm 0.8$ to $3.8 \pm 0.2$ and $3.7 \pm 0.7 \mathrm{AU}$ respectively (Figure 6a-c). As A23187 treatment did not result in the phosphorylation of Erk1/2 or JNK, DPI or mitoTEMPO treatment had no additional effect. These analyses show that increasing cytosolic $\mathrm{Zn}^{2+}$, but not $\mathrm{Ca}^{2+}$ results in phosphorylation of both $\mathrm{Erk1/2}$ and $\mathrm{JNK}$, in a manner that is dependent on NADPH oxidase and mitochondria activity.

Further experiments were performed to confirm the roles of Erk1/2 and JNK

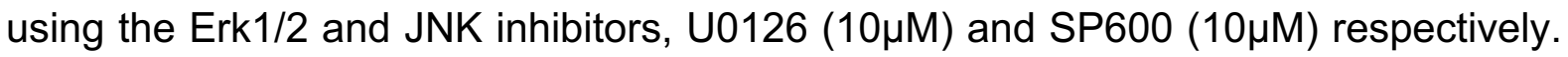


Pretreatment with either of these inhibitors decreased A23187 or clioquinol-mediated DHE fluorescence (Figure 6d). A23187-mediated DHE fluorescence was reduced from $2310 \pm 317 \mathrm{AU}$ to $1399 \pm 134 \mathrm{AU}$ and $393 \pm 149 \mathrm{AU}$ respectively following $\mathrm{U} 0128$ and SP600 treatment (Figure 6d, p<0.05). Clioquinol mediated DHE fluorescence was reduced from $2390.0 \pm 318 \mathrm{AU}$ to $1022 \pm 128 \mathrm{AU}$ and $739 \pm 104 \mathrm{AU}$ respectively following U0128 and SP600 treatment (Figure 6d, p<0.05). These data indicate that Erk1/2 and JNK phosphorylation occur downstream of ionophore treatment. Given that A23187 stimulation does not result in increases in Erk1/2 phosphorylation, these data indicate that Erk1/2 and JNK activation occurs as a result of changes in the concentration of cytosolic cations, and act on concert to regulate ROS production.

\section{Discussion}

The importance of ROS during platelet activation process is well documented. Stimulation of platelets with the conventional agonists, thrombin or CRP, results in increases in ROS production whilst the inhibitory effect of antioxidants function is correlated with a reduction in platelet responses.[50] Additionally, platelets can be activated by both extra- and intracellular free radical species.[15,51]

The influence of $\mathrm{Zn}^{2+}$ on ROS production in nucleated cells has been addressedFor example, in vitro studies showed that increases in cytosolic $\mathrm{Zn}^{2+}$ results in ROS generation in a number of nucleated cell systems.[27,31,52,53]

Hitherto, the influence of $\mathrm{Zn}^{2+}$ on ROS generation in platelets has not been investigated. Platelets are potentially exposed to $\mathrm{Zn}^{2+}$ via different routes. Exogenous $\mathrm{Zn}^{2+}$ is available to platelets from rupture of atherosclerotic plaques, and via release from a granules of activated platelets. Previously, we have shown that exogenous $\mathrm{Zn}^{2+}$ is able to enter the platelet cytosol where it influences platelet activation.[11] 
Chelation of $\left[\mathrm{Zn}^{2+}\right]_{i}$ reduced platelet aggregation in response to a variety of agonists, and also abrogated thrombus formation in an in vitro blood flow model.[11] Recently, we demonstrated that platelet stimulated with conventional platelet agonists induced dose-dependent increases of $\left[\mathrm{Zn}^{2+}\right]_{l}$, indicating release of $\mathrm{Zn}^{2+}$ into the cytosol from intracellular stores, and consistent a role for $\mathrm{Zn}^{2+}$ as a secondary messenger.[12]

Increases in $\left[\mathrm{Zn}^{2+}\right]_{i}$ are likely to modulate the activity of signalling pathways via the activation of kinases including PKC, CamKII and IRAK, in a similar way to $\mathrm{Ca}^{2+}-$ dependent signalling.[10,54,55] Whilst the influence of $\left[\mathrm{Ca}^{2+}\right]_{\mathrm{i}}$, on different redox systems and pathways is well documented, influences of $\left[\mathrm{Zn}^{2+}\right]_{i}$ on ROS generation is relatively unstudied.[56]

In the present study we model increases in $\left[\mathrm{Zn}^{2+}\right]$ i from endogenous and exogenous sources, and investigate the subsequent influence of, and mechanism of ROS generation. We demonstrate that increasing $\left[\mathrm{Zn}^{2+}\right]_{i}$ results in an increase in ROS generation, in a manner which is mediated by NADPH oxidase and mitochondria stimulation, and is regulated by Erk1/2 and JNK. Furthermore, we demonstrate that ROS production in response to platelet stimulation by conventional agonists (thrombin or $\mathrm{CRP}-\mathrm{XL})$ is also dependent on $\left[\mathrm{Zn}^{2+}\right]_{\text {i. }}$ Agonist stimulation results in increases in ROS production in a manner that is sensitive to intracellular $\mathrm{Zn}^{2+}$ chelation using TPEN. Whether agonist-dependent ROS stimulation is attributable to agonist-evoked increases in $\left[\mathrm{Zn}^{2+}\right]_{i}[57]$ or whether this represents a disruption of obligate $\mathrm{Zn}^{2+}$-binding proteins by TPEN, is not known. Using $\mathrm{ZnSO}_{4}$ as source of exogenous $\mathrm{Zn}^{2+}$, we found that $\mathrm{Zn}^{2+}$ dependent platelet stimulation results in increases in platelet ROS. Interestingly, whilst all $\mathrm{Zn}^{2+}$ concentrations tested result in increases in $\mathrm{ROS}$, the lowest concentration of $\mathrm{Zn}^{2+}$ used $(10 \mu \mathrm{M})$ results in the greatest ROS 
increases. As $10 \mu \mathrm{M} \mathrm{Zn}^{2+}$ is sub-activatory, we speculate that activation responses may reduce ROS by activating antioxidant responses within platelets. This is an interesting observation that will be studied further.

Ionophores were used to model increases of cation concentration on ROS generation. Importantly, whilst A23187 has been widely used to model increases in $\left[\mathrm{Ca}^{2+}\right]_{i}$, it should be noted that this is a non-specific ionophore, with affinities for a wide variety of cations, including $\mathrm{Zn}^{2+}$. Conversely, clioquinol is specific for $\mathrm{Zn}^{2+}$ and its use does not affect $\left[\mathrm{Ca}^{2+}\right]_{i \cdot[12,42]}$ Our data show that increases in the cytosolic concentration of either $\left[\mathrm{Ca}^{2+}\right]_{i}$ or $\left[\mathrm{Zn}^{2+}\right]_{i}$ correlates with increases in ROS. Whilst A23187-induced ROS generation could be attributable to $\mathrm{Ca}^{2+}$ or $\mathrm{Zn}^{2+}$ increases, $\mathrm{ROS}$ generation by clioquinol supports a role for $\left[\mathrm{Zn}^{2+}\right]_{i}$ in ROS generation that is independent of $\mathrm{Ca}^{2+}$. This is consistent with other work in nucleated cells, for example in cortical neurones, where ROS increases in response to treatment with the $\mathrm{Zn}^{2+}$ ionophore pyrithione.[31]

Both agonist- and ionophore-evoked ROS production is accompanied by decreases in GSH and GPx activity. Acting as an antioxidant, GSH suppress the excess production of intracellular oxidants. The reaction between glutathione peroxidase (GPx) and hydrogen peroxide, or of GSH with peroxynitrite and other oxidants results in the generation of glutathione oxidized form, GSSG, which is a marker of oxidative stress. $[58,59]$ By manipulation of $\left[\mathrm{Zn}^{2+}\right]_{\mathrm{i}}$ levels using $\mathrm{Zn}^{2+}$ chelators and ionophores, we show that the levels of GSH and GPx activity are altered in a $\left[\mathrm{Zn}^{2+}\right]_{i}$-dependent manner, confirming the involvement of $\left[\mathrm{Zn}^{2+}\right]_{i}$ and $\left[\mathrm{Ca}^{2+}\right]_{i}$ on platelet redox state modulation. These data are consistent with that of Bishop et al [52] who observed changes in GSH and GPx activity in astrocytes in response to $\mathrm{Zn}^{2+}$ ionophore treatment. 
We performed experiments to investigate the mechanisms by which $\mathrm{Zn}^{2+}$ regulates ROS production in platelets. NADPH oxidases (of which NOX1 and NOX2 isoforms are present in human platelets) are important ROS-generating enzymes. In neuronal cells, treatment with high concentrations of $\mathrm{Zn}^{2+}$ results in neurotoxicity that is associated with NADPH oxidase activation and PKC stimulation.[24] Alongside mitochondria activity, these enzymes regulate platelet activity via the regulation of redox- dependent ATP generation and ROS release.[60,61]

We examined the involvement of NOX and mitochondrial activity on $\left[\mathrm{Zn}^{2+}\right]$ idependent ROS using the NADPH oxidase inhibitor, DPI, and the mitochondrial targeted anti-oxidant, mitoTEMPO. Clioquinol-mediated ROS production was abrogated following pre-incubation of platelets with the DPI or mitoTEMPO, indicating a role for NADPH oxidase and mitochondria activity on $\left[\mathrm{Zn}^{2+}\right]$ i-dependent ROS production. Our observations are supported by previous studies, which showed that increases in $\left[\mathrm{Zn}^{2+}\right]_{i}$ promote p47phox activity in a neurotoxic environment.[24,31,45]

MAPK activity is critical for a number of intracellular signalling pathways in platelets, including $\alpha_{\| b} \beta_{3}$ activation, platelet granule release, thromboxane A2 (TxA2) generation, and cytoskeletal rearrangements leading to platelet spreading.[62,63] As $\mathrm{Zn}^{2+}$ has previously been shown to regulate MAPK activation in nucleated cells $[47,64,65]$ we investigated the influence of increases in $\mathrm{Zn}^{2+}$ on MAPK activity in platelets. Ionophore-dependent increases in $\left[\mathrm{Zn}^{2+}\right]_{\mathrm{i}}$, but not $\left[\mathrm{Ca}^{2+}\right]_{\mathrm{i}}$ resulted in increased phosphorylation of Erk1/2 and JNK, in a manner that has previously been observed in mouse thymocytes and splenic T cells. However, in contrast to our data phosphorylation of p38 MAPK was $\mathrm{Ca}^{2+}$ dependent, and JNK-1 activation was suppresses in a dose-dependent manner following incubation with A23187.[66] Such 
scheme has also been seen in NIH-3T3 mouse fibroblasts, where A23187 treatment was also shown to inhibits p38 MAPK phosphorylation].[67]

Agonist-dependent MAPK stimulation is abrogated following chelation of $\left[\mathrm{Zn}^{2+}\right]_{\text {. }}$. MAPK activation is modulated by cellular ROS levels, for example, in liver carcinoma cells (HepG2 cells), where ROS-JNK signalling promotes HBV-autophagosome formation.[68] LPS-mediated Nitric oxide (NO) release in response to $\mathrm{Zn}^{2+}$ treatment of astrocytes is associated with MAPK and NFKB activation.[49] Similar effects have been shown in renal cells, where $\mathrm{Zn}^{2+}$ promotes MAPK activation via ROS generation MAPK.[25, 26] Furthermore, in limb ischemia reperfusion, MAPKs are activated by ROS resulting in damage to distant organs.[69] Our results show that phosphorylation of Erk1/2 and JNK in platelets is regulated by $\left[\mathrm{Zn}^{2+}\right]$-mediated ROS generation via NADPH oxidase and mitochondria. This is consistent with previous studies, for example, in alveolar macrophages, where it was shown that Erk/2 effects mitochondrial integrity and ATP production, and pre-treatment with MEK inhibitors decreases Nox-5 phosphorylation in COS-7 cells.[70] Furthermore, In response to LPS, JNK promotes the stimulation of NADPH oxidase during NETosis in neutrophils.[71] In this context, our data show that the induction of platelet ROS generation in response to increases in $\left[\mathrm{Zn}^{2}\right] \mathrm{i}$, is reduced in response to Erk1/2 and JNK inhibitors, presenting a positive feedback loop between $\mathrm{Zn}^{2+}$-dependent ROS induction and MAPK phosphorylation. Given the importance of MAPKs in platelet activation leading to thrombus formation,[72] identification of $\mathrm{Zn}^{2+}$-sensitive MAPK activation in platelets may highlight a potentially significant route through leading to thrombus formation following plaque rupture.

In summary, our findings establish an association between $\left[\mathrm{Zn}^{2+}\right]_{i}$ and $\mathrm{ROS}$ production in platelets, providing evidence that $\left[\mathrm{Zn}^{2+}\right]_{i}$ stimulates NADPH oxidase and 
mitochondria via Erk1/2 and JNK activation, and these MAPKs promote an increase of ROS by a positive feedback (Figure 7). These data explain the involvement in $\mathrm{Zn}^{2+}$ in platelet redox balance, which is a key process during platelet activation.[15] Pharmacological manipulation of $\mathrm{Zn}^{2+}$ might be a potential strategy to moderate oxidative stress, which is a pivotal feature of cardiovascular diseases.

\section{Acknowledgements}

This work was supported by British Heart Foundation project grants (PG /15/2/31224 and $P G / 17 / 76 / 33082$ to Jonathan Martin Gibbins, $P G / 14 / 47 / 30912$ and PG/18/64/33922 to Nicholas Pugh, and PG/15/40/31522 to Giordano Pula).

\section{Authorship Contributions}

MLP, NA, GP, DV and NP designed and conducted experiments, and wrote the manuscript. JG wrote the manuscript.

\section{Competing Interests}

The authors declare no conflicts of interest. 


\section{Figure Legends}

Figure 1. Exogenous $\mathrm{Zn}^{2+}$ stimulates ROS production by platelets. Platelet suspensions were loaded with the ROS-sensitive dye, DHE $(10 \mu \mathrm{M})$ and stimulated with increasing concentrations of $\mathrm{Zn}^{2+}$. Changes in the fluorescent signal after $10 \mathrm{~min}$ were quantified by flow cytometry (a). Results are presented as means \pm SEM of 7 independent experiments. Significance is denoted as ${ }^{* *}(P<0.001),{ }^{* *}(P<0.01)$, or * $(\mathrm{P}<0.05)$. ESR was used to further demonstrate $\mathrm{Zn}^{2+}$-dependent superoxide anion production. Platelet suspensions were loaded with superoxide-specific spin probe $\mathrm{CMH}$ and treated for Platelets were treated for 45 minutes with $200 \mu \mathrm{M} d \mathrm{RP}$, vehicle (Tyrode's buffer, black) or $10 \mu \mathrm{M}$ (blue), $30 \mu \mathrm{M}$ (grey), $100 \mu \mathrm{M}$ (red) or $300 \mu \mathrm{M}$ (green) of $\mathrm{ZnSO}_{4}$ in the presence of $\mathrm{CMH}(200 \mu \mathrm{M})$ prior to ESR analysis. The trace is representative of 3 independent experiments (b).

Figure 2. ROS production in response to platelet stimulation is dependent on $\left[\mathrm{Zn}^{2+}\right]_{i}$. DHE-loaded washed platelet suspensions were pre-incubated with the intracellular $\mathrm{Zn}^{2+}$ chelator, TPEN $(50 \mu \mathrm{M})$ prior to stimulation with thrombin $(1 \mathrm{U} / \mathrm{mL})$ or CRP-XL $(1 \mu \mathrm{g} / \mathrm{mL})$. Changes in DHE fluorescence were analysed by flow cytometry (a). Changes to glutathione (GSH) (b) and glutathione peroxidase activity (GPx) (c) in response to $\mathrm{Zn}^{2+}$ were measured by ELISA. Results are presented as means \pm SEM values of between 3 and 5 experiments. Significance is denoted as *** $(P<0.001)$, ** $(P<0.01)$, or * $(P<0.05)$.

Figure 3. Increasing platelet $\left[\mathrm{Zn}^{2+}\right]_{i}$ by stimulation with $\mathrm{Zn}^{2+}$ ionophores results in increased ROS production. DHE-Loaded washed platelet suspensions were 
stimulated with clioquinol $(100 \mu \mathrm{M})$ or $\mathrm{A} 23187(100 \mu \mathrm{M})$, and fluorescence changes were quantified using flow cytometry (a). Superoxide anion production following

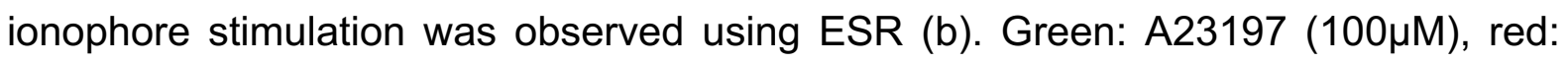
clioquinol $(100 \mu \mathrm{M})$, black: vehicle control. To visualise ionophore-dependent ROS production, platelets were loaded with DHE and imaged using confocal microscopy following stimulation with clioquinol $(100 \mu \mathrm{M})$ or $\mathrm{A} 23187(100 \mu \mathrm{M})(\mathrm{c})$. In order to quantify ROS-dependent changes in response to increasing concentrations of $\left[\mathrm{Zn}^{2+}\right]$, washed platelet suspensions were incubated with clioquinol $(100 \mu \mathrm{M})$ or $\mathrm{A} 23187$ $(100 \mu \mathrm{M})$ for $10 \mathrm{~min}$. Reduced glutathione (GSH) (d) and glutathione peroxidase activity (GPx) (e) were quantified by ELISA. Results are presented as mean \pm SEM values of between 3 and 5 experiments. Significance is denoted as * $(P<0.05)$.

Figure 4. $\left[\mathrm{Zn}^{2+}\right]$ i-mediated ROS generation is regulated by NADPH oxidase and mitochondria activation. DHE-loaded washed platelet suspensions were pre-

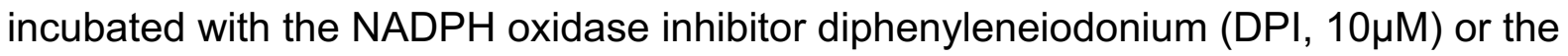

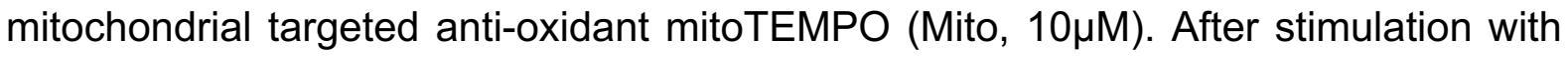
clioquinol $(100 \mu \mathrm{M})$ or $\mathrm{A} 23187(100 \mu \mathrm{M})$, ROS generation was analysed by flow cytometry. Results are representative of 6 independent experiments (a). Washed platelet suspensions were stimulated with clioquinol $(100 \mu \mathrm{M})$ or A23187 $(100 \mu \mathrm{M})$, after which they were subjected to subcellular fractionation, and phosphorylation of p47phox was analysed by immunoblotting (b). The immunoblot is representative of 3 independent experiments. Blots were analysed using densitometry (c). Results are presented as means \pm SEM. Significance is denoted as ${ }^{* * *}(P<0.001)$, ${ }^{* *}(P<0.01)$ or ${ }^{*}(P<0.05)$. 
Figure 5. Agonist-dependent MAPK activation is dependent on $\left[\mathrm{Zn}^{2+}\right]_{\mathrm{i}}$. Washed

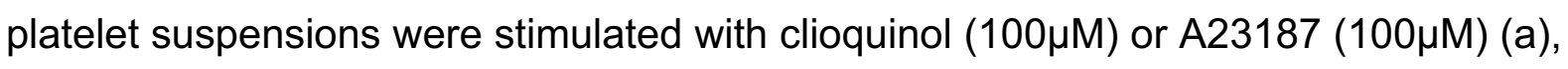
or pre-incubated with TPEN $(50 \mu \mathrm{M})$ followed stimulation by thrombin $(1 \mathrm{U} / \mathrm{mL})$ or CRP$\mathrm{XL}(1 \mu \mathrm{g} / \mathrm{mL})(\mathrm{d})$. After subcellular fractionation, phosphorylation of Erk1/2 or JNK was analysed by Immunoblotting. Graphs show densitometric analysis of immunoreactive bands P-Erk (a, b, d, e), or P-JNK (a, c, d, f). Results are presented as means \pm SEM values of 3 independent experiments. Significance is denoted as ** $(P<0.001)$, ** $(P<0.01)$, or * $(P<0.05)$.

Figure 6. $\mathrm{Zn}^{2+}$, but not $\mathrm{Ca}^{2+}$-mediated ROS generation induces Erk1/2 and JNK phosphorylation. Washed platelet suspensions were pre-incubated with DPI $(10 \mu \mathrm{M})$ or mitoTEMPO (Mito, $10 \mu \mathrm{M})$ prior to stimulation with clioquinol $(100 \mu \mathrm{M})$ or $\mathrm{A} 23187$ $(100 \mu \mathrm{M})$. Phosphorylation of Erk1/2, or JNK were examined by immunoblotting as before (a-c). Blots are representative of 3 separate experiments. DHE-loaded washed platelet suspensions were pretreated with the Erk1/2 and JNK inhibitors U0126 (10 $\mu \mathrm{M})$ and SP600 $(10 \mu \mathrm{M})$ respectively, prior to stimulation with $\mathrm{A} 23187(100 \mu \mathrm{M})$ or clioquinol $(100 \mu \mathrm{M})$. Changes in DHE fluorescence were quantified using flow cytometry (d). Results are presented as means \pm SEM. Significance is denoted as *** $(P<0.001)$, ** $(P<0.01)$ or * $(P<0.05)$.

Figure 7: Schematic showing the proposed role of $\mathrm{Zn}^{2+}$ in platelet $\mathrm{ROS}$ generation. Agonist stimulation (1) or local increases in plasma $\mathrm{Zn}^{2+}$ as a result of platelet degranulation or atherosclerotic plaque rupture (2) result in increases in $\left[\mathrm{Zn}^{2+}\right]_{\mathrm{i}}$ (3). Increases in $\left[\mathrm{Zn}^{2+}\right]_{i}$ results in the activation of $\mathrm{NADPH}$ oxidase (4) and mitochondria (5), resulting in an increase of ROS generation (6). ROS-mediated 
phosphorylation of the MAPKs, Erk1/2 and JNK results in a positive feedback loop in which these MAPKs further induce ROS production (7). 


\section{References}

[1] Badimon L, Vilahur G. Thrombosis formation on atherosclerotic lesions and plaque rupture. J Intern Med 2014. 276:618-32.

[2] Badimon L, Padró T, Vilahur G. Atherosclerosis, platelets and thrombosis in acute ischaemic heart disease. Eur Heart J Acute Cardiovasc Care 2012. 1:60-74.

[3] Passam FH, Giannakopoulos B, Mirarabshahi P, Krilis SA. Molecular pathophysiology of the antiphospholipid syndrome: the role of oxidative posttranslational modification of beta 2 glycoprotein I. J Thromb Haemost 2011. 9 Suppl 1:275-82.

[4] Lansdown AB, Mirastschijski U, Stubbs N, Scanlon E, Agren MS. Zinc in wound healing: theoretical, experimental, and clinical aspects. Wound Repair Regen 2007. 15:2-16.

[5] Lansdown AB. Zinc in the healing wound. Lancet 1996. 347:706-7.

[6] Milne DB, Ralston NV, Wallwork JC. Zinc content of cellular components of blood: methods for cell separation and analysis evaluated. Clin Chem 1985. 31:65-9.

[7] Whitehouse RC, Prasad AS, Rabbani PI, Cossack ZT. Zinc in plasma, neutrophils, lymphocytes, and erythrocytes as determined by flameless atomic absorption spectrophotometry. Clin Chem 1982. 28:475-80.

[8] Gordon PR, Woodruff CW, Anderson HL, O'Dell BL. Effect of acute zinc deprivation on plasma zinc and platelet aggregation in adult males. Am J Clin Nutr 1982. 35:113-9.

[9] Emery MP, O’Dell BL. Low zinc status in rats impairs calcium uptake and aggregation of platelets stimulated by fluoride. Proc Soc Exp Biol Med Exp Biol Med N Y N 1993. 203:480-4. 
[10] Taylor KA, Pugh N. The contribution of zinc to platelet behaviour during haemostasis and thrombosis. Metallomics 2016. 8:144-55.

[11] Watson B, White N, Taylor K, Howes J-M, Malcor J-D, Bihan D, Sage, SO, Farndale, RW and Pugh N. Zinc is a Transmembrane Agonist that Induces Platelet Activation in a Tyrosine Phosphorylation-Dependent Manner. Metallomics 2016. 8:91-100.

[12] Ahmed NS, Lopes Pires ME, Taylor KA, Pugh N. Agonist-Evoked Increases in Intra-Platelet Zinc Couple to Functional Responses. Thromb Haemost 2019.119:128-39.

[13] Yang X, Li Y, Li Y, Ren X, Zhang X, Hu D, Gao, Y, Zing, Y and Shang, H. Oxidative Stress-Mediated Atherosclerosis: Mechanisms and Therapies. Front Physiol 2017. 8:600.

[14] He W, Liu Y, Wamer WG, Yin J-J. Electron spin resonance spectroscopy for the study of nanomaterial-mediated generation of reactive oxygen species. J Food Drug Anal 2014. 22:49-63.

[15] Pietraforte D, Vona R, Marchesi A, de Jacobis IT, Villani A, Del Principe D, and Straface, E. Redox control of platelet functions in physiology and pathophysiology. Antioxid Redox Signal 2014. 21:177-93.

[16] Qiao J, Arthur JF, Gardiner EE, Andrews RK, Zeng L, Xu K. Regulation of platelet activation and thrombus formation by reactive oxygen species. Redox Biol 2018. $14: 126-30$.

[17] Kalyanaraman B. Teaching the basics of redox biology to medical and graduate students: Oxidants, antioxidants and disease mechanisms. Redox Biol 2013. $1: 244-57$. 
[18] Delaney MK, Kim K, Estevez B, Xu Z, Stojanovic-Terpo A, Shen B, Ushio-Fukai M, Cho J, and Du X. Differential Roles of the NADPH-Oxidase 1 and 2 in Platelet Activation and Thrombosis. Arterioscler Thromb Vasc Biol 2016. 36:846-54.

[19] Vara D, Cifuentes-Pagano E, Pagano PJ, Pula G. A novel combinatorial technique for simultaneous quantification of oxygen radicals and aggregation reveals unexpected redox patterns in the activation of platelets by different physiopathological stimuli. Haematologica 2019. 104:1879-91.

[20] Chen Q, Wang Q, Zhu J, Xiao Q, Zhang L. Reactive oxygen species: key regulators in vascular health and diseases. Br J Pharmacol 2018. 175:1279-92.

[21] Halliwell B, Gutteridge JMC. Free Radicals in Biology and Medicine. Oxford University Press; 2015.

[22] Klaunig JE, Kamendulis LM, Hocevar BA. Oxidative stress and oxidative damage in carcinogenesis. Toxicol Pathol 2010. 38:96-109.

[23] Valko M, Izakovic M, Mazur M, Rhodes CJ, Telser J. Role of oxygen radicals in DNA damage and cancer incidence. Mol Cell Biochem 2004. 266:37-56.

[24] Noh KM, Koh JY. Induction and activation by zinc of NADPH oxidase in cultured cortical neurons and astrocytes. J Neurosci Off J Soc Neurosci 2000. 20:RC111.

[25] Aimo L, Cherr GN, Oteiza PI. Low extracellular zinc increases neuronal oxidant production through nadph oxidase and nitric oxide synthase activation. Free Radic Biol Med 2010. 48:1577-87.

[26] Matsunaga Y, Kawai Y, Kohda Y, Gemba M. Involvement of activation of NADPH oxidase and extracellular signal-regulated kinase (ERK) in renal cell injury induced by zinc. J Toxicol Sci 2005. 30:135-44. 
[27] Patrushev N, Seidel-Rogol B, Salazar G. Angiotensin II requires zinc and downregulation of the zinc transporters $\mathrm{ZnT3}$ and $\mathrm{ZnT} 10$ to induce senescence of vascular smooth muscle cells. PloS One 2012. 7:e33211.

[28] Salazar G, Huang J, Feresin RG, Zhao Y, Griendling KK. Zinc regulates Nox1 expression through a NF-KB and mitochondrial ROS dependent mechanism to induce senescence of vascular smooth muscle cells. Free Radic Biol Med 2017. 108:225-35.

[29] Sensi SL, Yin HZ, Weiss JH. AMPA/kainate receptor-triggered $\mathrm{Zn}^{2+}$ entry into cortical neurons induces mitochondrial $\mathrm{Zn}^{2+}$ uptake and persistent mitochondrial dysfunction. Eur J Neurosci 2000. 12:3813-8.

[30] Dineley KE, Richards LL, Votyakova TV, Reynolds IJ. Zinc causes loss of membrane potential and elevates reactive oxygen species in rat brain mitochondria. Mitochondrion 2005. 5:55-65.

[31] Clausen A, McClanahan T, Ji SG, Weiss JH. Mechanisms of rapid reactive oxygen species generation in response to cytosolic $\mathrm{Ca}^{2+}$ or $\mathrm{Zn}^{2+}$ loads in cortical neurons. PloS One 2013. 8:e83347.

[32] Vande Voorde J, Ackermann T, Pfetzer N, Sumpton D, Mackay G, Kalna G, Nixon C, Blyth K, Gottlieb E, and Tardito S. Improving the metabolic fidelity of cancer models with a physiological cell culture medium. Sci Adv 2019. 5:eaau7314.

[33] Gibbins JM. Techniques for analysis of proteins by SDS-polyacrylamide gel electrophoresis and Western blotting. Methods Mol Biol 2004. 273:139-52.

[34] Palomo I, Toro C, Alarcón M. The role of platelets in the pathophysiology of atherosclerosis. Mol Med Rep 2008. 1:179-84. 
[35] Lopes Pires ME, Clarke SR, Marcondes S, Gibbins JM. Lipopolysaccharide potentiates platelet responses via toll-like receptor 4-stimulated Akt-Erk-PLA2 signalling. PloS One 2017. 12:e0186981.

[36] Trybulec M, Kowalska MA, McLane MA, Silver L, Lu W, Niewiarowski S. Exposure of platelet fibrinogen receptors by zinc ions: role of protein kinase $\mathrm{C}$. Proc Soc Exp Biol Med 1993. 203:108-16.

[37] Aquilano K, Baldelli S, Ciriolo MR. Glutathione: new roles in redox signaling for an old antioxidant. Front Pharmacol 2014. 5:196.

[38] Oliveira PVS, Laurindo FRM. Implications of plasma thiol redox in disease. Clin Sci 2018.132:1257-80.

[39] Marx G, Korner G, Mou X, Gorodetsky R. Packaging zinc, fibrinogen, and factor XIII in platelet alpha-granules. J Cell Physiol 1993. 156:437-42.

[40] Bolsover SR, Kater SB, Guthrie PB. Spatial gradients of cytosolic calcium concentration in neurones during paradoxical activation by calcium. Cell Calcium 1996. 20:373-9.

[41] Schnetkamp PP, Li XB, Basu DK, Szerencsei RT. Regulation of free cytosolic $\mathrm{Ca}^{2+}$ concentration in the outer segments of bovine retinal rods by $\mathrm{Na}-\mathrm{Ca}-\mathrm{K}$ exchange measured with fluo-3. I. Efficiency of transport and interactions between cations. J Biol Chem 1991. 266:22975-82.

[42] Fujikawa K, Fukumori R, Nakamura S, Kutsukake T, Takarada T, Yoneda Y. Potential interactions of calcium-sensitive reagents with zinc ion in different cultured cells. PloS One 2015. 10:e0127421.

[43] Aiba I, West AK, Sheline CT, Shuttleworth CW. Intracellular dialysis disrupts $\mathrm{Zn}^{2+}$ dynamics and enables selective detection of $\mathrm{Zn}^{2+}$ influx in brain slice preparations. J Neurochem 2013. 125:822-31. 
[44] Przygodzki T, Sokal A, Bryszewska M. Calcium ionophore A23187 action on cardiac myocytes is accompanied by enhanced production of reactive oxygen species. Biochim Biophys Acta BBA - Mol Basis Dis 2005. 1740:481-8.

[45] El-Benna J, Dang PM-C, Gougerot-Pocidalo MA, Marie JC, Braut-Boucher F. p47phox, the phagocyte NADPH oxidase/NOX2 organizer: structure, phosphorylation and implication in diseases. Exp Mol Med 2009. 41:217-25.

[46] DeLeo FR, Quinn MT. Assembly of the phagocyte NADPH oxidase: molecular interaction of oxidase proteins. J Leukoc Biol 1996. 60:677-91.

[47] Nimmanon T, Ziliotto S, Morris S, Flanagan L, Taylor KM. Phosphorylation of zinc channel ZIP7 drives MAPK, PI3K and mTOR growth and proliferation signalling. Met Integr Biometal Sci 2017. 9:471-81.

[48] Ohashi K, Nagata Y, Wada E, Zammit PS, Shiozuka M, Matsuda R. Zinc promotes proliferation and activation of myogenic cells via the PI3K/Akt and ERK signaling cascade. Exp Cell Res 2015. 333:228-37.

[49] Moriyama M, Fujitsuka S, Kawabe K, Takano K, Nakamura Y. Zinc Potentiates Lipopolysaccharide-induced Nitric Oxide Production in Cultured Primary Rat Astrocytes. Neurochem Res 2018. 43:363-74.

[50] Freedman JE. Oxidative stress and platelets. Arterioscler Thromb Vasc Biol 2008. 28:s11-16.

[51] Lopes-Pires ME, Casarin AL, Pereira-Cunha FG, Lorand-Metze I, Antunes E, Marcondes S. Lipopolysaccharide treatment reduces rat platelet aggregation independent of intracellular reactive-oxygen species generation. Platelets 2012. 23:195-201. 
[52] Bishop GM, Dringen R, Robinson SR. Zinc stimulates the production of toxic reactive oxygen species (ROS) and inhibits glutathione reductase in astrocytes. Free Radic Biol Med 2007. 42:1222-30.

[53] Guo D, Bi H, Liu B, Wu Q, Wang D, Cui Y. Reactive oxygen species-induced cytotoxic effects of zinc oxide nanoparticles in rat retinal ganglion cells. Toxicol Vitro Int J Publ Assoc BIBRA 2013. 27:731-8.

[54] Yamasaki S, Sakata-Sogawa K, Hasegawa A, Suzuki T, Kabu K, Sato E, Kurosaki T, Yamashita S, Tokunaga M, Nishida K, Hirano T. Zinc is a novel intracellular second messenger. J Cell Biol 2007. 177:637-45.

[55] Haase H, Maret W. Fluctuations of cellular, available zinc modulate insulin signaling via inhibition of protein tyrosine phosphatases. J Trace Elem Med Biol 2005. 19:37-42.

[56] Görlach A, Bertram K, Hudecova S, Krizanova O. Calcium and ROS: A mutual interplay. Redox Biol 2015. 6:260-71.

[57] Ahmed S, Kozma R, Lee J, Monfries C, Harden N, Lim L. The cysteine-rich domain of human proteins, neuronal chimaerin, protein kinase $C$ and diacylglycerol kinase binds zinc. Evidence for the involvement of a zincdependent structure in phorbol ester binding. Biochem J 1991. 280 (Pt 1):23341.

[58] Ashfaq S, Abramson JL, Jones DP, Rhodes SD, Weintraub WS, Hooper WC, Vaccarino V, Harrison DG, and Quyyumi AA. The relationship between plasma levels of oxidized and reduced thiols and early atherosclerosis in healthy adults. J Am Coll Cardiol 2006. 47:1005-11. 
[59] Rahal A, Kumar A, Singh V, Yadav B, Tiwari R, Chakraborty S, and Dhama K. Oxidative stress, prooxidants, and antioxidants: the interplay. BioMed Res Int 2014. $2014: 761264$.

[60] Vara D, Campanella M, Pula G. The novel NOX inhibitor 2-acetylphenothiazine impairs collagen-dependent thrombus formation in a GPVI-dependent manner. Br J Pharmacol 2013. 168:212-24.

[61] Garcia-Souza LF, Oliveira MF. Mitochondria: biological roles in platelet physiology and pathology. Int J Biochem Cell Biol 2014. 50:156-60.

[62] Li Z, Xi X, Du X. A mitogen-activated protein kinase-dependent signaling pathway in the activation of platelet integrin alpha Ilbbeta3. J Biol Chem 2001. 276:4222632.

[63] Kyriakis JM, Avruch J. Mammalian MAPK signal transduction pathways activated by stress and inflammation: a 10-year update. Physiol Rev 2012. 92:689-737.

[64] Azriel-Tamir H, Sharir H, Schwartz B, Hershfinkel M. Extracellular zinc triggers ERK-dependent activation of $\mathrm{Na}^{+} / \mathrm{H}^{+}$exchange in colonocytes mediated by the zinc-sensing receptor. J Biol Chem 2004. 279:51804-16.

[65] Hönscheid A, Dubben S, Rink L, Haase H. Zinc differentially regulates mitogenactivated protein kinases in human T cells. J Nutr Biochem 2012. 23:18-26.

[66] Zhang, J, Salojin, KV, Gao, JX, Cameron, MJ, Bergerot, I, Delovitch, TL. p38 mitogen-activated protein kinase mediates signal integration of TCR/CD28 costimulation in primary murine T cells. J Immunol 1999. 162:3819-29.

[67] Koeberle A, Pergola C, Shindou H, Koeberle SC, Shimizu T, Laufer SA, and Werz O. Role of p38 mitogen-activated protein kinase in linking stearoyl-CoA desaturase-1 activity with endoplasmic reticulum homeostasis. FASEB J 2015. 29:2439-49. 
[68] Zhong L, Shu W, Dai W, Gao B, Xiong S. Reactive Oxygen Species-Mediated cJun NH2-Terminal Kinase Activation Contributes to Hepatitis B Virus X ProteinInduced Autophagy via Regulation of the Beclin-1/Bcl-2 Interaction. J Virol 2017. 91. 15: pii: e00001-17

[69] Choi EK, Yeo J-S, Park CY, Na H in, Lim J a, Lee J-E, Hong SW, Park SS, Lim DG, and Kwak $\mathrm{KH}$. Inhibition of reactive oxygen species downregulates the MAPK pathway in rat spinal cord after limb ischemia reperfusion injury. Int J Surg 2015. 22:74-8.

[70] Pandey D, Fulton DJR. Molecular regulation of NADPH oxidase 5 via the MAPK pathway. Am J Physiol-Heart Circ Physiol 2011. 300:H1336-44.

[71] Khan MA, Farahvash A, Douda DN, Licht J-C, Grasemann H, Sweezey N, and Palaniyar, N. JNK Activation Turns on LPS- and Gram-Negative Bacteria-Induced NADPH Oxidase-Dependent Suicidal NETosis. Sci Rep 2017;7(1):3409

[72] Flaumenhaft R, Dilks JR, Rozenvayn N, Monahan-Earley RA, Feng D, Dvorak AM. The actin cytoskeleton differentially regulates platelet alpha-granule and dense-granule secretion. Blood 2005;105:3879-87. 
Figure 1

A

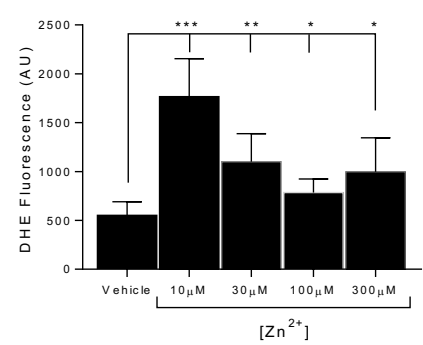

B

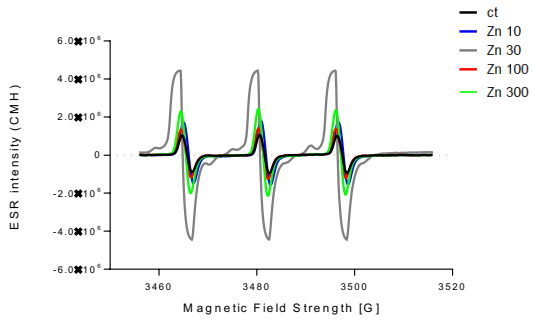


Figure 2

A

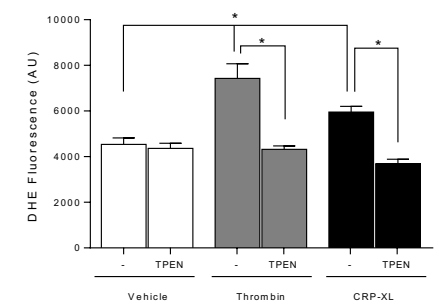

B
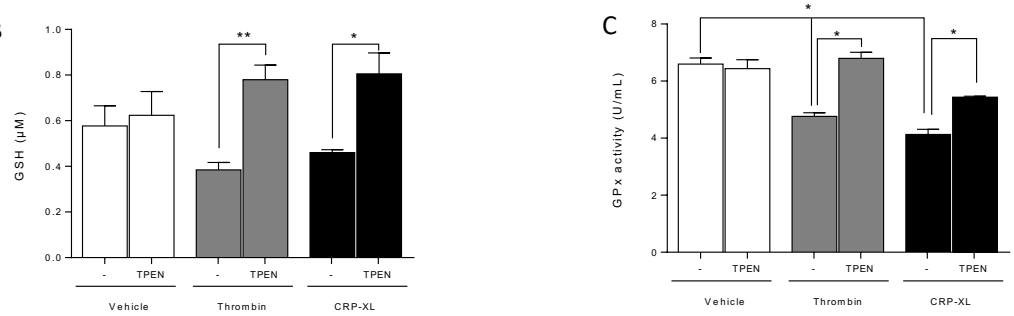
Figure 3

A

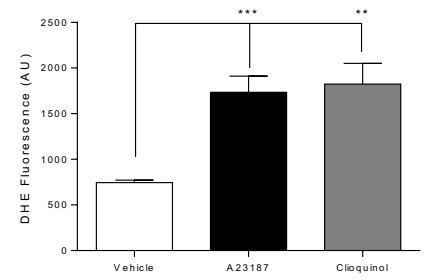

C

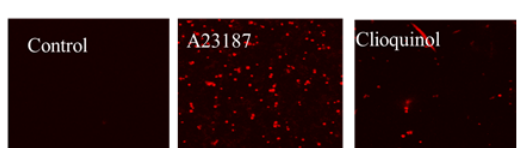

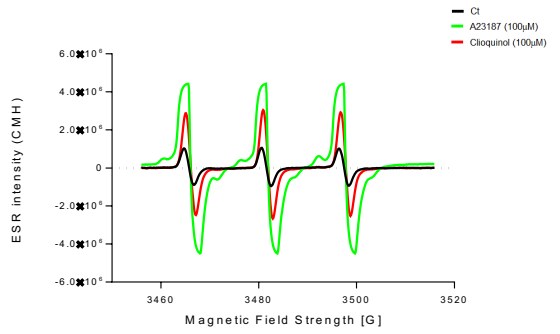

D
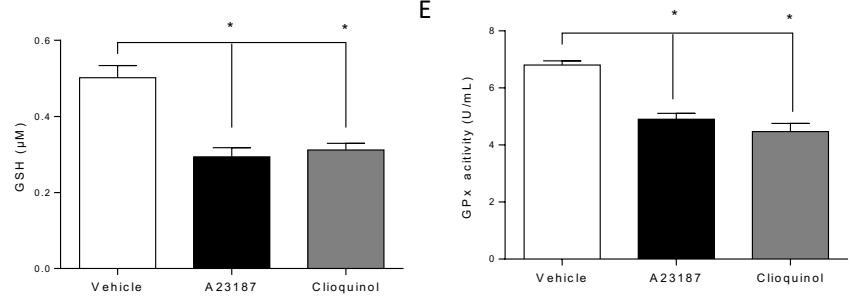
Figure 4

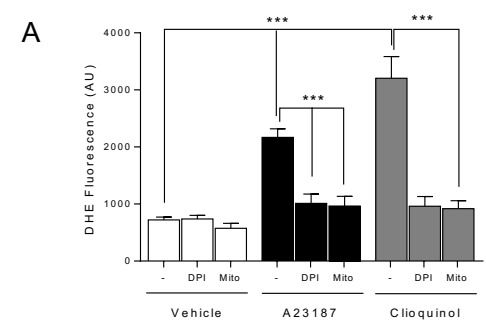

B Phospho-p47phox

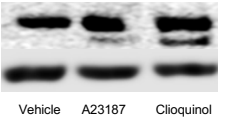

C

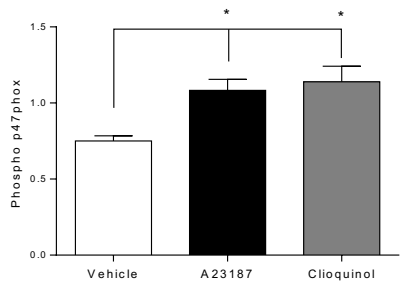


Figure 5

A
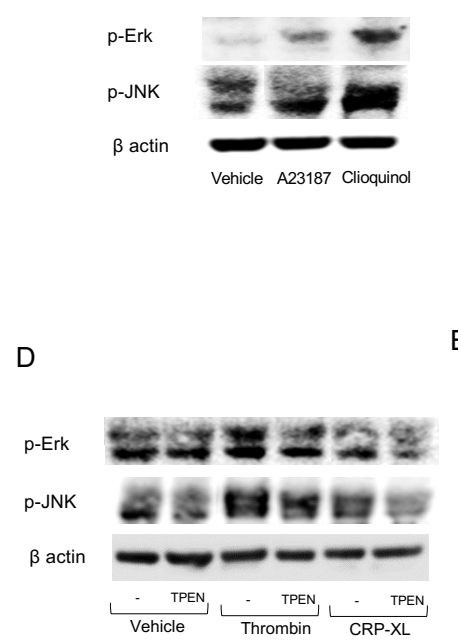

B
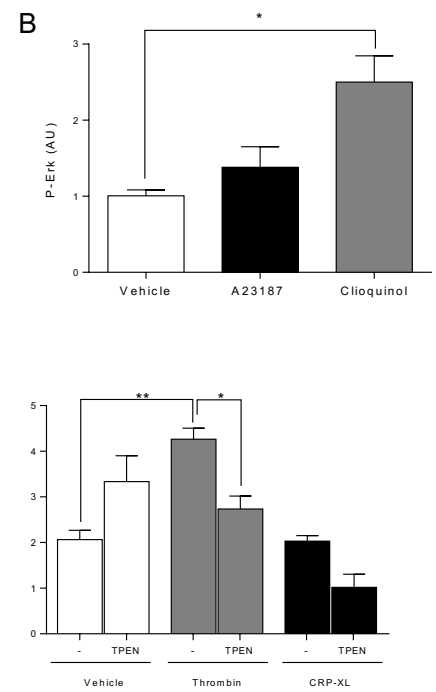

C

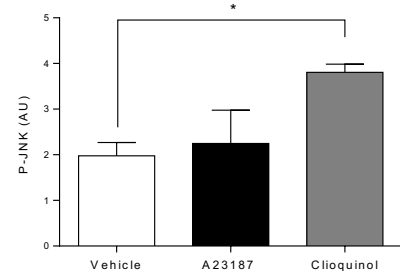

F

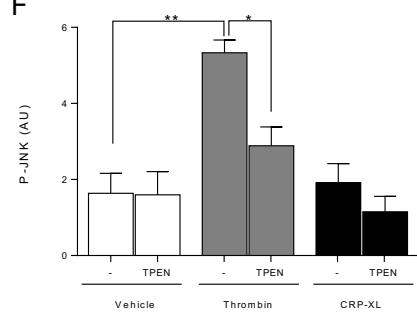


Figure 6

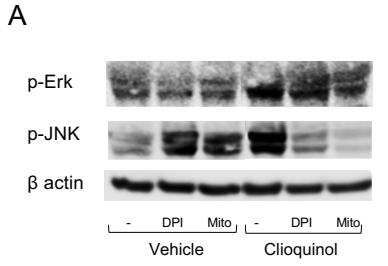

B

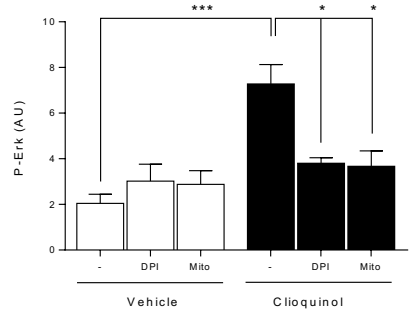

C

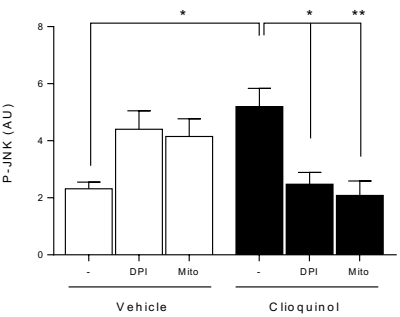

D

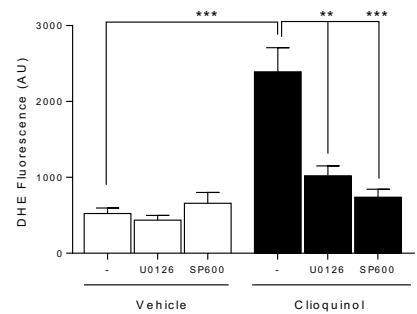




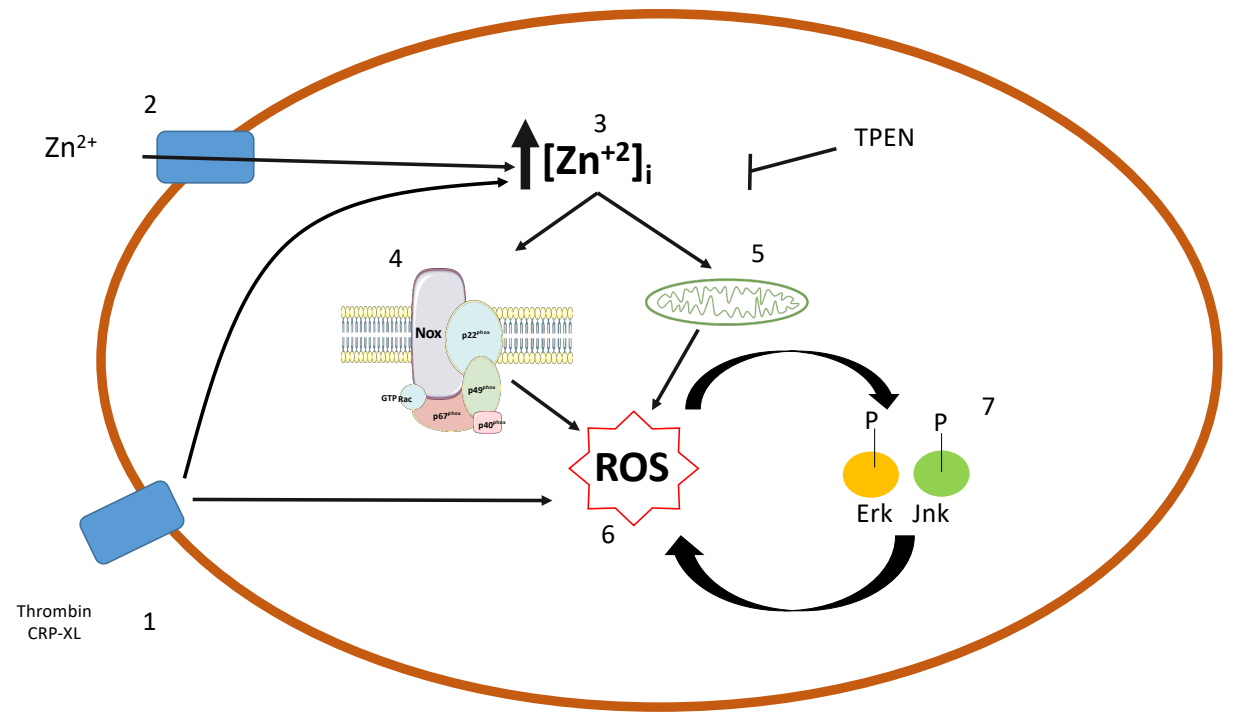

